\title{
Innovation, Entrepreneurial Skills and Ethics: The Impact of a Pilot Program on Students in European Union Aged 13 - 15
}

\author{
Konstantina Tsoli, Thomas Babalis \\ Department of Pedagogy and Primary Education (GREECE), National and Kapodistrian University of Athens, Athens, Greece \\ Email: nadtso@primedu.uoa.gr, tbabalis@primedu.uoa.gr
}

How to cite this paper: Tsoli, K., \& Babalis, T. (2021). Innovation, Entrepreneurial Skills and Ethics: The Impact of a Pilot Program on Students in European Union Aged 13 15. Psychology, 12, 1364-1378. https://doi.org/10.4236/psych.2021.129085

Received: July 28, 2021

Accepted: September 11, 2021

Published: September 14, 2021

Copyright (c) 2021 by author(s) and Scientific Research Publishing Inc. This work is licensed under the Creative Commons Attribution International License (CC BY 4.0).

http://creativecommons.org/licenses/by/4.0/

(c) (i) Open Access

\begin{abstract}
In the European Commission's policy, entrepreneurship has emerged as the main responsibility of European education and special attention has been given to the development of entrepreneurial skills, such as critical and creative thinking, problem solving, decision making, innovation, risk-taking, etc. The purpose of this study is to present the impact of "ETHICSBOARD", a 6-month pilot training course, designed in 2019 to teach entrepreneurial concepts accompanied with ethical practices, to school students aged 13 - 15 in Greece, Spain and Portugal. The training curriculum and learning materials were developed on six basic areas (personal empowerment, critical and creative thinking, effective decision making and problem solving, entrepreneurship and vocational training, Project-Based Learning and school-family-community partnerships), which were based on innovative, learner-centered pedagogical approaches and creative techniques. Specifically, one hundred and eighteen (118) students completed a questionnaire, developed by the researchers, before and after the implementation of the pilot course, in order to identify any changes in their knowledge, skills and attitudes towards ethics and entrepreneurship. The results showed that in the post-measure, compared to the pre-measure, the students showed higher mean values in many of the variables examined. Implications for policy, practice, and research are also explored.
\end{abstract}

\section{Keywords}

Innovation, Entrepreneurial Skills, Ethical Values, Educational Program, Training Course

\section{Introduction}

Entrepreneurial education is critical both for developing entrepreneurial skills, 
attitudes and behaviors that are the basis for economic growth (wide definition) as well as for setting up a venture and becoming self-employed (narrow definition) (Erkkilä, 2000; Lackéus, 2015). Entrepreneurship and entrepreneurial skills are core components to meeting the global challenges of the 21st century and advancing human welfare (GEM, 2020). "Entrepreneurship refers to an individual s ability to turn ideas into action. It includes creativity, innovation and taking calculated risk, as well as the ability to plan and manage projects in order to achieve objectives. This supports everyone in day-to-day life at home and in society, but also in the workplace in being aware of the context of their work and being able to seize opportunities, and is a foundation for more specific skills and knowledge needed by those establishing or contributing to social and commercial activity. This should include awareness of ethical values and promote good governance" (European Commission, 2006: p. 1010). This common European understanding of entrepreneurship indicates that it is a key competence, which focuses on two aspects. The first one refers to the capability of an individual to turn ideas into action, after the development of entrepreneurial attitudes, skills and knowledge. The second one emphasizes that entrepreneurship is not only related to economic activities and business creation, but more widely to all areas of life and society. This is one of the main reasons the term of entrepreneurship creates confusion (Lackéus, 2015) when referring to education. Some believe that it encourages and stimulates students to start their own company; however, entrepreneurial education is not just about teaching someone how to create and manage a business; it is about encouraging critical, creative and innovative thinking and promoting a strong sense of self-confidence, empowerment and team spirit (European Commission, 2008). The Danish foundation for entrepreneurship (2014) distinguishes the notion of "entrepreneurship as a method" from "entrepreneurship as an occupation", highlighting that it does not necessarily aim at increasing students' desire to become an entrepreneur, but at strengthening their non-cognitive entrepreneurial skills, such as creativity, innovation, etc.

In the previous years, the number one priority of European Commission was to support entrepreneurship for creating new jobs and growth, but after the financial and migrant crisis in Europe, it was realized that the growth must be based on ethical values that advance inclusion, respect to diversity, equality, gender-balance \& non-discrimination. Ethics come from the ancient Greek word "ethos", which refers to established habits, to the character of man. Ethics is the study of the morals of a society and the system of rules of thinking and behavior that regulates the attitudes of a society at a certain time. Ethical education programs are becoming more and more frequent nowadays, as a result of the decline of moral and positive social behavior (Kohlberg, 1984; Lickona, 1991). Therefore, the education of ethics to students is highly innovative and directly linked to the concept of sustainable entrepreneurship practices. Dr. Weinstein

${ }^{1}$ Recommendation of the European Parliament and of the Council of 18 December 2006 on key competences for lifelong learning, OJ L 394, 30.12.2006. 
(2009), in his best seller book "Is It Still Cheating, If I Don't Get Caught?" concludes, based on a research to 30.000 school students by Josephson Institute of Ethics, that currently schools still lack teaching ethics appropriately in an entrepreneurship context. According to Weinstein, this is very dangerous, since children today, are looking to the culture at large for ethical guidance, and many adults are not setting a good example, while parents along with teachers have a key role on setting that example.

Entrepreneurial education is arguably one of the most important steps for cultivating a creative and innovative culture, which could, alongside with ethics, prepare the new wave of citizens (Volkmann, Wilson, Mariotti, Rapuzzi, Vyakarnam, \& Sepulveda, 2009). Entrepreneurial education started over a century ago, with organizations-pioneers, such as the non-profit educational institution "Junior Achievement", which was founded in 1918 and delivers thereafter hands on, experiential learning in work readiness, financial literacy, and entrepreneurship (Farrell, 2018). However, entrepreneurship has emerged in different educational contexts, with alternative definitions and a variation of objectives depending on the level of education. At primary education level most of the European countries include entrepreneurship in central steering documents, while at upper secondary education level almost all countries integrate entrepreneurship into the curriculum in some form (Lackéus, 2015). More specifically, at primary education level, entrepreneurial education is included in the curriculum largely as a cross-curricular objective, while at upper secondary education level, it is included in the curriculum either as an optional separate subject or integrated in other subjects (e.g. social sciences, economics and business studies). Conclusively, in many European countries, not all students reach entrepreneurial education, because it is optional or not a cross-curricular theme (European Commission/EACEA/Eurydice, 2016). In higher education institutions, entrepreneurship has been part of the curriculum for almost 70 years. The first graduate course in entrepreneurship was offered at Harvard University in 1947 (Katz, 2003). Today, entrepreneurship courses are offered increasingly at universities all over the world (Gibb, 2005).

The main objective of entrepreneurial education is to transmit the appropriate attitudes (e.g. self-awareness, self-confidence), knowledge (e.g. learn the opportunities that exist in terms of professional career and the world of job) and skills (e.g. communication, presentation, programming skills and teamwork) to students in order to behave in an entrepreneurial way (Lackéus, 2014). European Commission (2013) advocated that every student should have at least one practical entrepreneurial experience (e.g. running a mini-company) before completing compulsory education. Entrepreneurial education encompasses innovation, since the pedagogy applied should move beyond the limits of traditional teaching methods and should be based on the active role of learners (learning by doing) and their collaboration, while failure must be accepted as part of the learning process (Gibb, 2005). Experiential and empirical learning are considered to be the most effective educational approaches for entrepreneurial education that lead to deep learning, which is the result of the shared interaction. Stu- 
dents acquire and apply entrepreneurial skills, such as creativity, problem solving, decision making, strategic thinking, the possibility of concluding agreements, time management, persuasion, negotiating and encouraging (Babalis \& Tsoli, 2017). Indicative tools, models and theories that have a more explicit focus on value creation rather than venture creation are effectuation, business model canvas, appreciative inquiry, service-learning, design thinking, etc. (Lackéus, 2015).

The researchers, taking into account the literature review and having detected the gap both in entrepreneurial education and research, designed and implemented in 2019 a 6-month pilot training course on Ethics and Entrepreneurship (E \& E) (acronym "ETHICSBOARD”) to school students aged 13 - 15 in Greece, Spain and Portugal. The selection of these three Mediterranean countries derives from the fact that entrepreneurship remains primarily elective and is not integrated across the curriculum, thus the inclusion of entrepreneurial education depends to a great extent on the will of the teachers (Tsoli \& Babalis, 2021). The purpose of the study was to present the differences among pre-measure (before the training course) and post-measure (after the training course) in the total sample of students that participated with regards to the meaning and the benefits of entrepreneurial education, the entrepreneurial skills and the relation between entrepreneurship and ethics.

\section{Methodology}

\subsection{Participants}

One hundred and eighteen (118) students volunteered to participate in the study. From the total sample, forty-four $(44,37.3 \%)$ were from Greece, twenty-nine $(29,24.6 \%)$ were from Spain, and forty-five $(45,38.1 \%)$ were coming from Portugal (Figure 1). The majority of the participants were female, as sixty-four $(64,54.2 \%)$ women and fifty-four $(54,45.8 \%)$ men participated in the study (Figure 2). Regarding students' age, forty (40,33.9\%) were thirteen years old, sixty-two $(62,52.5 \%)$ were fourteen years old, and sixteen $(16,13.6 \%)$ students were fifteen (15) years old (Figure 3).

\subsection{Questionnaire Statistical Analysis}

In order to identify the needs regarding ethics and entrepreneurship in education, the researchers carried out a user needs analysis to teachers, students and entrepreneurs using mixed methods (qualitative \& quantitative data). Teachers were asked to complete a questionnaire and were interviewed at each participating school about the learning context at their school and their children's needs with regard to their learning of entrepreneurship and ethics, engagement, motivation and self-efficacy. Data were also gathered from student participants in three ways: 1) interviews, 2) surveys and 3) content analysis of reflective documents produced (e.g. posters, videos, students' diaries, etc.). Finally, entrepreneurs were also interviewed and contributed to the program by detailing their 
individual perspective on entrepreneurial education. After completing the analysis, the researchers developed a training program and learning materials on teaching and learning of entrepreneurship and ethics.

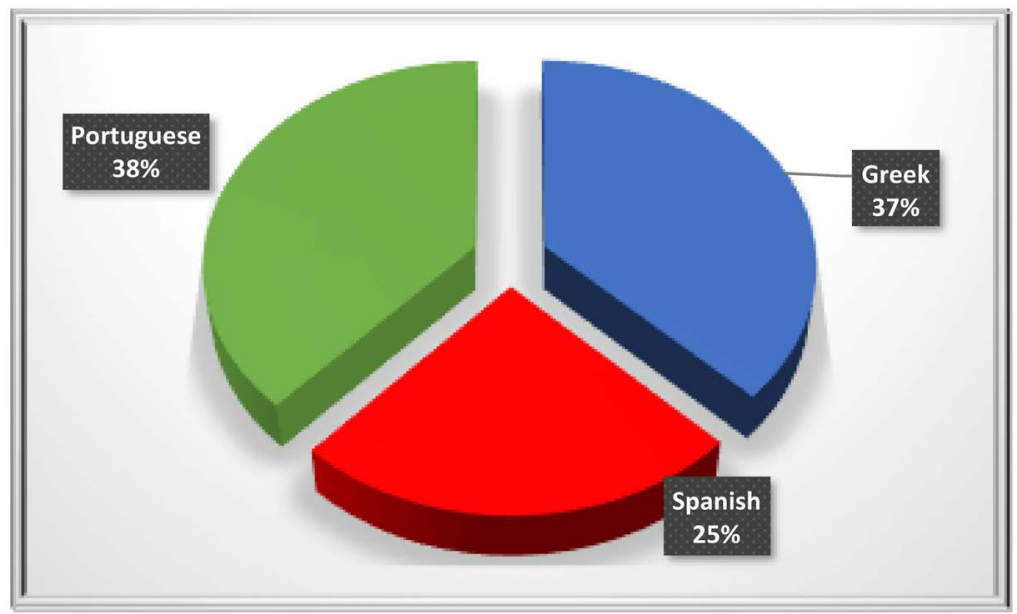

Figure 1. Students' percentage based on their nationality.

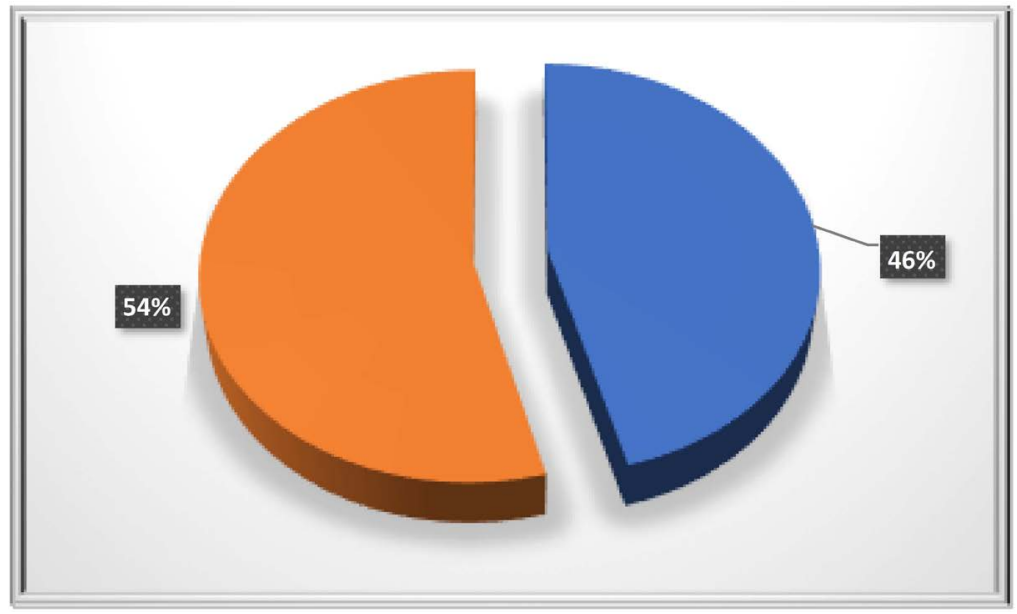

Figure 2. Students' percentage based on their gender.

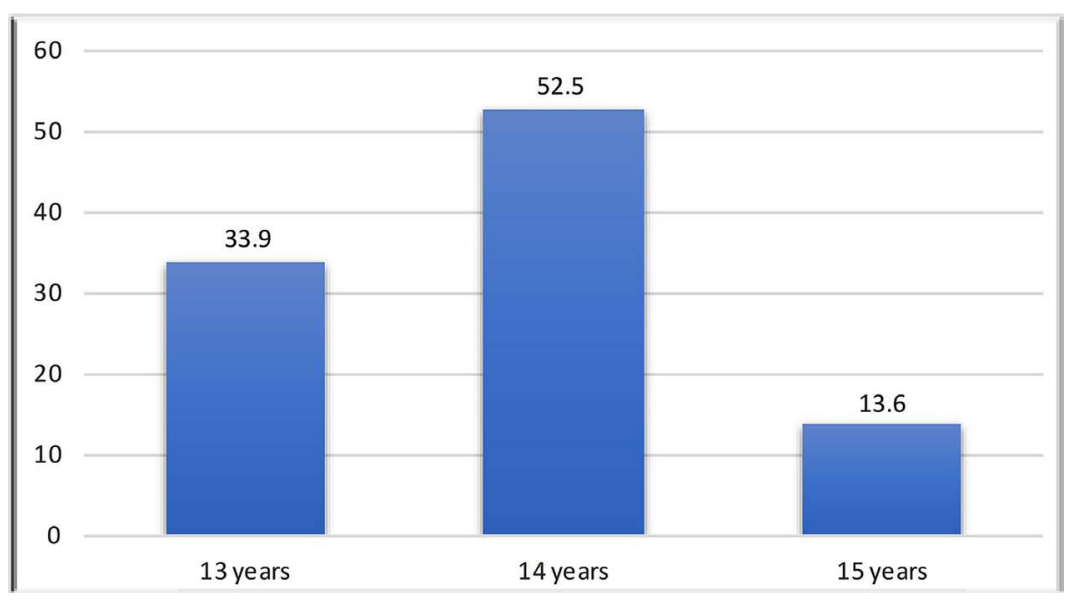

Figure 3. Students' percentage based on their age. 
The present study presents the results of the survey to students, aiming at capturing their perceived entrepreneurial knowledge and attitudes before and after the educational intervention. The researchers developed, among others, a questionnaire for students, based on the literature review, the state of the art in Greece, Spain and Portugal where the program was implemented, and the user needs analysis. The questionnaire consisted of two parts: 1) Demographic information (nationality, gender, age, class) and 2) Education for Entrepreneurship. The questionnaire was a 6-items-set self-report scale, aiming in general at identifying what entrepreneurial education is, what are its benefits, which skills are considered entrepreneurial and what is the relation between entrepreneurship and ethics. Each one of the 6-items-set consisted of 4 to 7 answers for which students selected the degree to which it expressed best their opinion. The participants provided their responses based on a 7/point Likert type scale with anchors of "strongly disagree" (1) to "strongly agree" (7), whereas (4) represented "neither agree nor disagree".

The exploratory factor analysis indicated acceptable factor structure as well as reliability for the factors of the instrument used. The factors' internal consistency (Cronbach a) ranged from .71 to .83. Additionally, univariate and multivariate statistical analyses were conducted in order to examine whether students differ significantly between the pre-test and post-test (Wilks' Lambda, $F$-values, $p$-values, partial $\eta^{2}$ ). Follow-up ANOVAs were performed on the subscales where there were significant MANOVA effects (Tukey test). Bonferroni adjustment was applied to control for the inflation of Type I error (Tabachnick \& Fidell, 2006). The means $(M)$ and standard deviations $(S D)$ were also examined.

\subsection{The Pilot Program}

"ETHICSBOARD" addresses the integration of entrepreneurship into education from school age, combining entrepreneurial culture with ethical education. Its main purpose is to provide psychosocial provision to students with skills necessary in a variety of areas throughout their life. Self-responsibility, self-awareness and self-esteem, the development of communication and intercultural skills, critical, creative thinking and problem-solving are fundamental thematic axes of entrepreneurial education. However, the cultivation of the above is considered fruitful and necessary to coexist with the direct and indirect ethical education of the students. The main scope of "ETHICSBOARD" is to help all students achieve high-quality skills and provide them the necessary support, in order to be prepared for the demands of the society, as future European and global citizens. The main objectives of the program are to:

develop and promote entrepreneurial education based on codes of ethics and advance from the early age the sense of individual responsibility;

cultivate entrepreneurial skills (e.g. solving problems, responsible decision making, communication, self-awareness, interpersonal and inter-cultural skills, etc.) and

develop entrepreneurial skills based on ethical values by using innovative and 
learner-centered pedagogical approaches.

The teaching material that has been developed for this purpose includes: three training Curricula (for teachers, students and parents) a Teaching Portfolio and a Learning Portfolio on Ethics and Entrepreneurship (E \& E).

The program was developed on six basic axes:

0 . Ice-Breakers

1. Empowering yourself

2. Creative and critical thinking

3. Effective decision-making and problem-solving

4. Entrepreneurship and career counselling

5. Project-Based Learning (PBL)

6. School-Family-Community partnership

At this point, we present two indicative activities aiming at cultivating students' creative and critical thinking.

$1^{\text {st }}$ Activity: The 10 Euros challenge (estimated time: 1 teaching hour)

The teacher asks students the following question: "You have 10 Euros in your pocket. What would you do to earn money if all you had was 10 Euros? List as many entrepreneurial ideas you can come up with". This activity is based on the brainstorming technique, where students are asked to plan for an activity to increase an initial small amount of money. The following guidelines are given:

Step 1: Write the question on the board into a circle. Ask some of your students to paraphrase the question, in order to make sure that they have understood it.

Step 2: Divide your students into groups of 4 - 5 persons. Ask them to open their workbook and write the question on the spider's body (Figure 4). In each group, each student gives an answer to the question, which is written on the spider's feet. In case a student cannot think of an answer, he/she says "pass" and the group moves on with the next person. No one is allowed to criticize their classmates' answer.

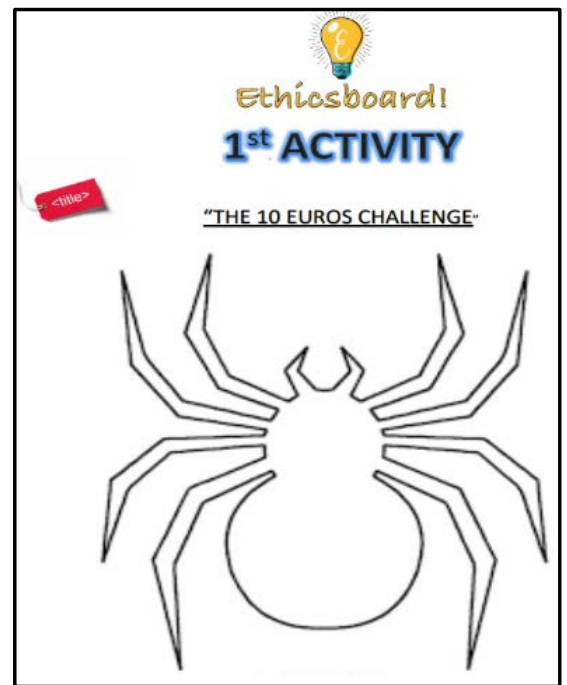

Figure 4. The spider's body for the brainstorming technique. 
Step 3: The same procedure is being repeated until everyone says "pass".

Step 4: When all groups have finished, a student which takes the role of the "secretary" writes all the answers on the board, and afterwards all together, teacher and students, categorize the answers after having discarded versions that are copies of other versions.

Step 5: After completing the procedure, a discussion takes place with the following indicative questions: What do you need to start a business? What characteristics are successful to be an entrepreneur? Which one do you think is the most creative idea? Did you consider the question as an opportunity and challenging assumption?

The purpose of the activity is for students to realize that money is not the most important element for starting a business. The most important thing is to be proactive, creative and to try to achieve your goals.

$2^{\text {nd }}$ Activity: The art of scampering (estimated time: 2 teaching hours)

2.1 ( $1^{\text {st }}$ teaching hour). The teacher has written on the board some well-known enterprises and asks students to add to the list others that they know. Example list: * Tesla * Adidas * Ryanair * Google's self-driving cars * Heineken * Benetton * Enterprises of students' choice ... Then, the teacher asks students to select an enterprise and name one of its products (e.g. one electric car from Tesla or a pair of Adidas shoes). In groups, students apply the "SCAMPER" technique and create a new product (Figure 5).

2.2 ( $2^{\text {nd }}$ teaching hour). The teacher asks students if they know the plot of the Iron Man movie. The choice of the movie is due to the fact that the entrepreneur Elon Musk was, according to its director, the inspiration for the basic character of the movie. We then give them some information on: 1) Elon Musk and 2) the plot of the movie. In groups, students apply the "SCAMPER" technique and write a new story (Figure 6).

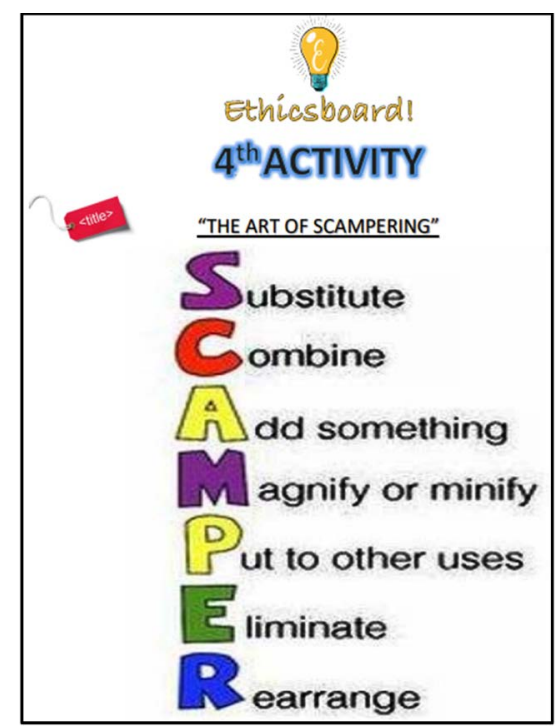

Figure 5. Creating a new product: the "SCAMPER" technique. 


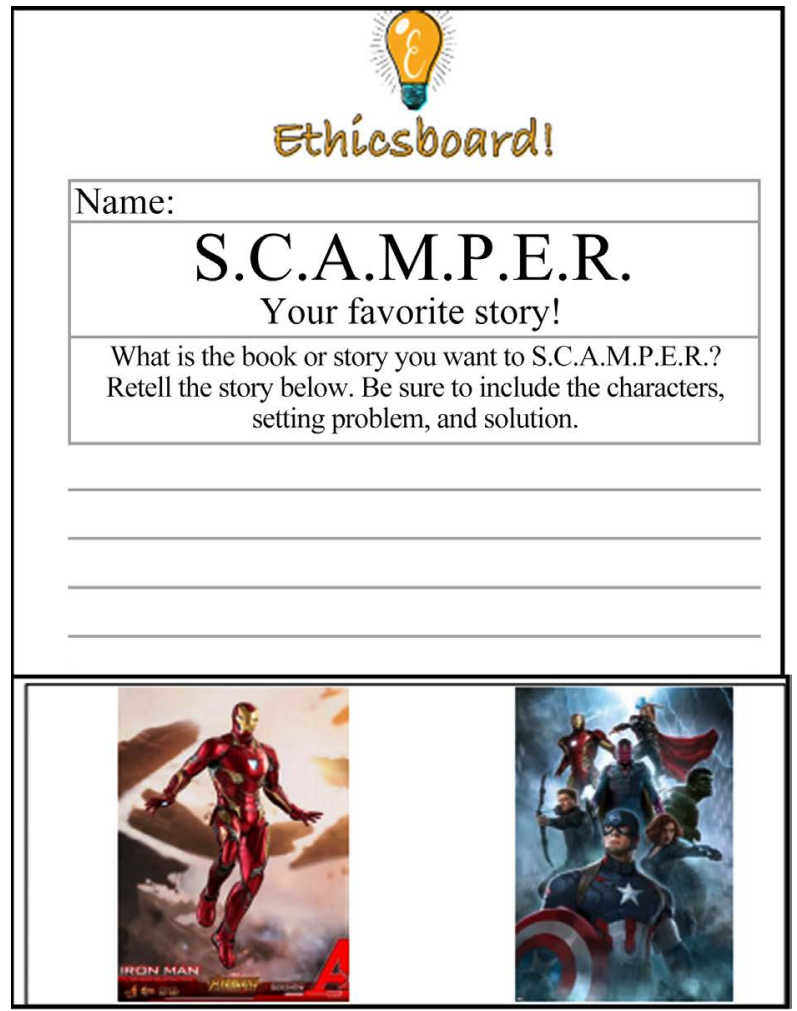

Figure 6. Writing a new story: the "SCAMPER" technique.

\section{Results}

The differences among pre-measure (before the training course) and post-measure (after the training course) in the total sample of students that participated in the study (Greece, Spain, Portugal) are presented in Figures 7-10. In each figure, the means $(M)$ and the level of significant difference ( $F$-value) of the examined variables are presented.

Figure 7 presents the means $(M)$, the standard deviations $(S D)$ and the differences ( $F$-values) among pre-measure and post-measure regarding the meaning of entrepreneurial education. The multiple analysis of variance for repeated measures (RMANOVA) indicated significant differences between the pre-measure and post-measure (Wilks' Lambda $=.880, F=6.465, p<.001$, partial $\left.\eta^{2}=.120\right)$. Subsequent analysis indicated significant differences by students in object construction for charity or other purpose $\left(F=31.372, p<.001, \eta_{p}^{2}\right.$ $=.098$ ), and sale of students' constructions for various activities (e.g., seminars, excursions, etc. $)\left(F=6.197, p<.05, \eta_{p}^{2}=.021\right)$.

The second set of questions that students responded refer to the entrepreneurial skills in education (Figure 8). The results showed significant differences among pre-measure and post-measure regarding all entrepreneurial skills. The multiple analysis of variance for repeated measures (RMANOVA) indicated significant differences between the pre-measure and post-measure (Wilks' Lambda $=.880, F=11.115, p<.001$, partial $\left.\eta^{2}=.190\right)$. Subsequent analysis indicated significant differences in: 1 ) problem solving and responsible decision making ( $F=$ 


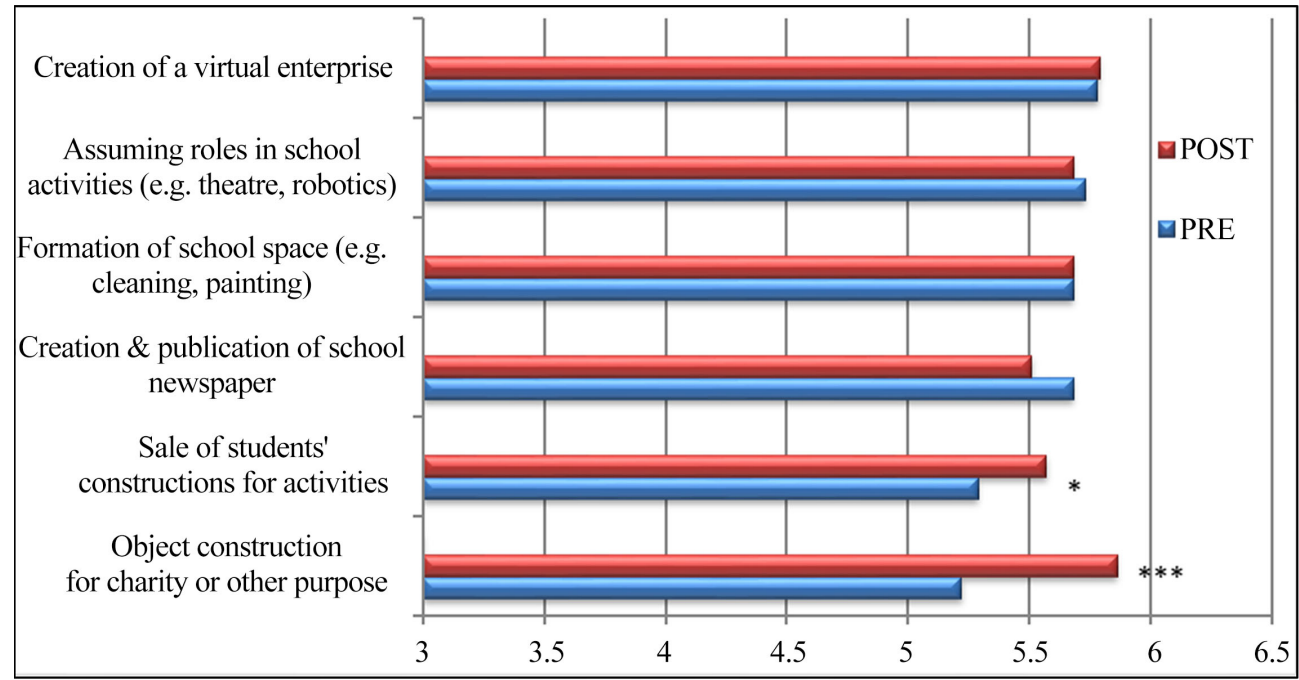

Figure 7. Means $(M)$, Standard Deviations $(S D)$ and Differences ( $F$-values) among pre-measure and post-measure regarding the Meaning of Entrepreneurial Education. ${ }^{\star} p<.05,{ }^{* *} p<.01,{ }^{\star * *} p<.001$.

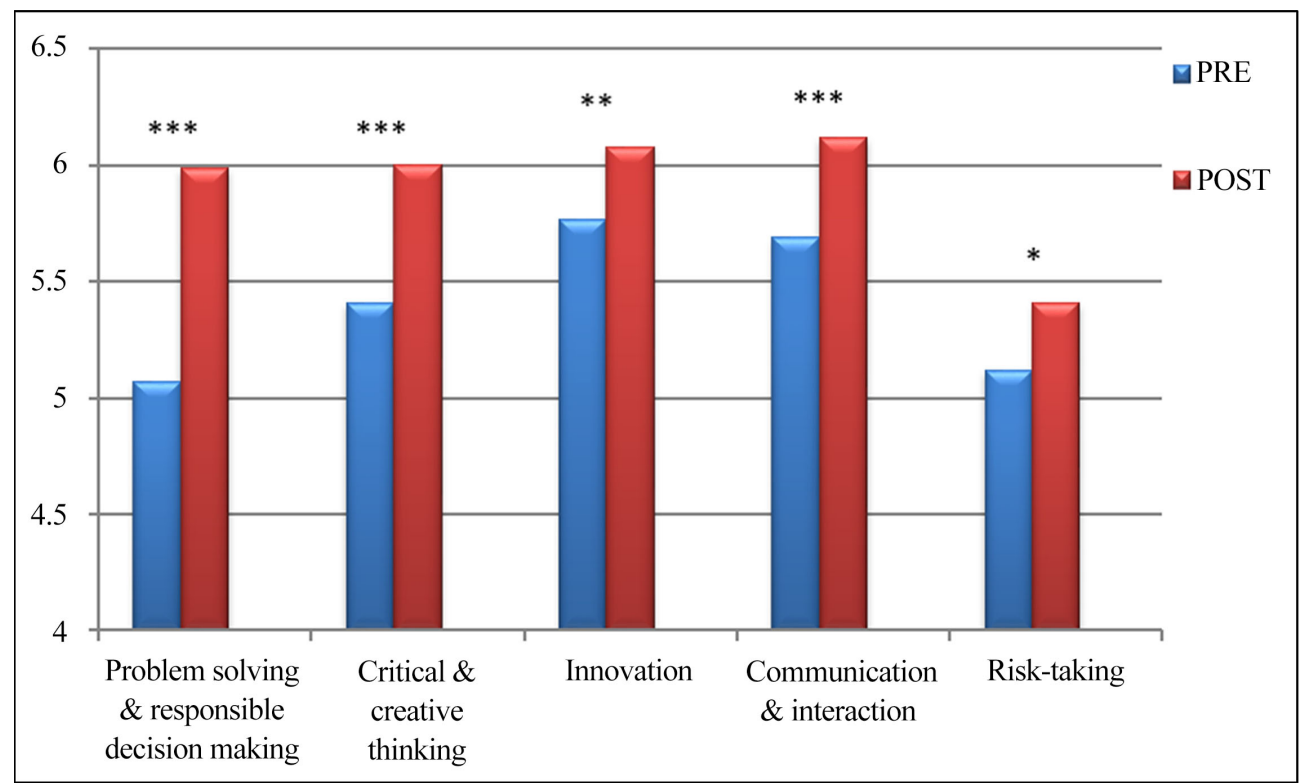

Figure 8. Means $(M)$, Standard Deviations $(S D)$ and Differences ( $F$-values) among pre-measure and post-measure regarding the Entrepreneurial Skills in Education. ${ }^{\star} p<.05,{ }^{\star *} p<.01,{ }^{\star * *} p<.001$.

60.750, $\left.\left.p<.001, \eta_{p}^{2}=.170\right), 2\right)$ critical and creative thinking $(F=29.403, p$ $\left.\left.<.001, \eta_{p}^{2}=.092\right), 3\right)$ innovation $\left.\left(F=7.721, p<.01, \eta_{p}^{2}=.026\right), 4\right)$ communication and interaction $\left(F=15.886, p<.001, \eta_{p}^{2}=.052\right)$, and 5) risk-taking $(F$ $\left.=4.889, p<.05, \eta_{p}^{2}=.017\right)$.

Figure 9 presents students' responses with regard to the entrepreneurship and ethics concepts. The results showed significant differences between the pre-measure and the post-measure regarding the meaning of "entrepreneurship and ethics". The multiple analysis of variance for repeated measures (RMANOVA) indicated significant differences between the pre-measure and post-measure (Wilks' Lambda $=.929, F=3.620, p<.01$, partial $\eta^{2}=.071$ ). Sub- 
sequent analysis indicated significant differences in: 1$)$ values/value system ( $F=$ 5.750, $\left.\left.p<.05, \eta_{p}^{2}=.070\right), 2\right)$ justice $\left.\left(F=9.340, p<.01, \eta_{p}^{2}=.082\right), 3\right)$ cooperation $\left(F=15.397, p<.001, \eta_{p}^{2}=.051\right)$, and 4$)$ freedom of opinion and expres$\operatorname{sion}\left(F=6.889, p<.01, \eta_{p}^{2}=.047\right)$.

The differences among pre-measure and post-measure after the training course with regard to the contribution of the education for entrepreneurship and ethics are presented in Figure 10. The results showed significant differences among the students of the three countries (Greece, Spain, Portugal) between the pre- and post-measure. The multiple analysis of variance for repeated measures (RMANOVA) indicated significant differences between the pre-measure and post-measure (Wilks' Lambda $=.929, F=3.620, p<.01$, partial $\eta^{2}=.071$ ). Subsequent analysis indicated significant differences in: 1) students' socialization

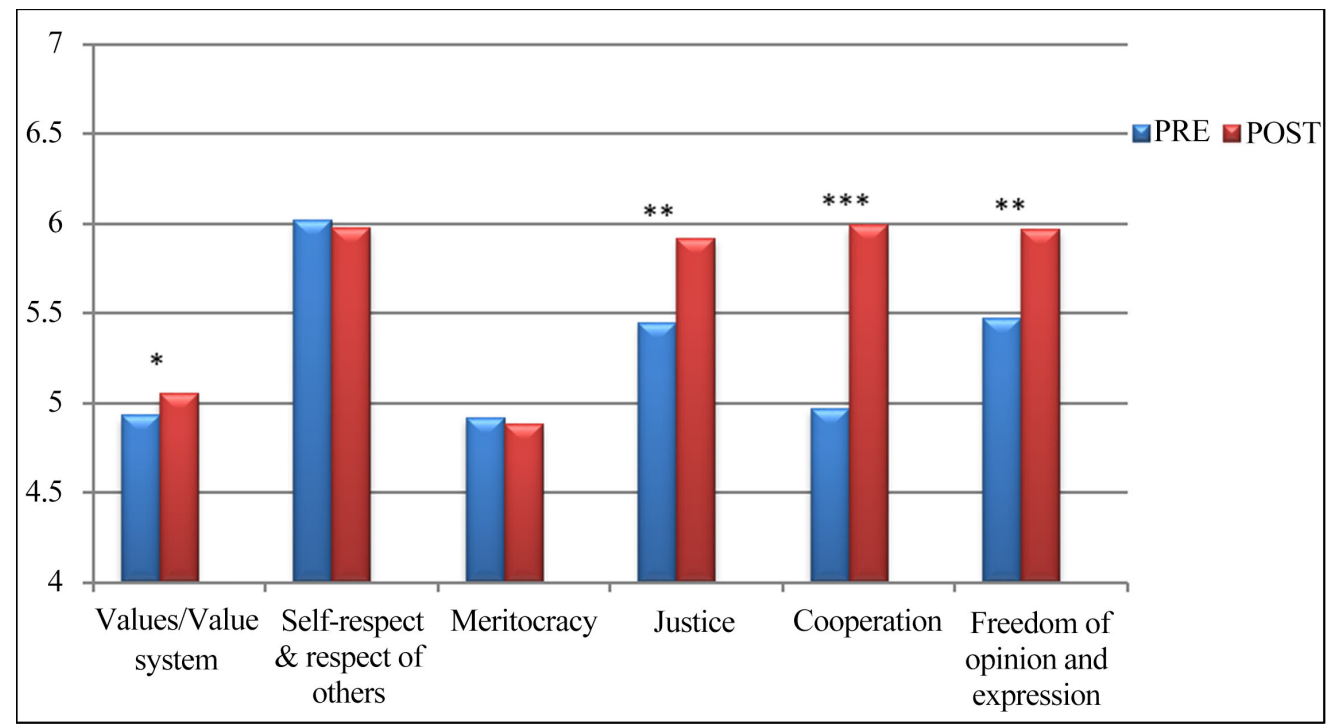

Figure 9. Means $(M)$, Standard Deviations $(S D)$ and Differences ( $F$-values) among pre-measure and post-measure regarding the Entrepreneurship and Ethics Concepts. ${ }^{\star} p<.05,{ }^{\star *} p<.01,{ }^{\star * \star} p<.001$.

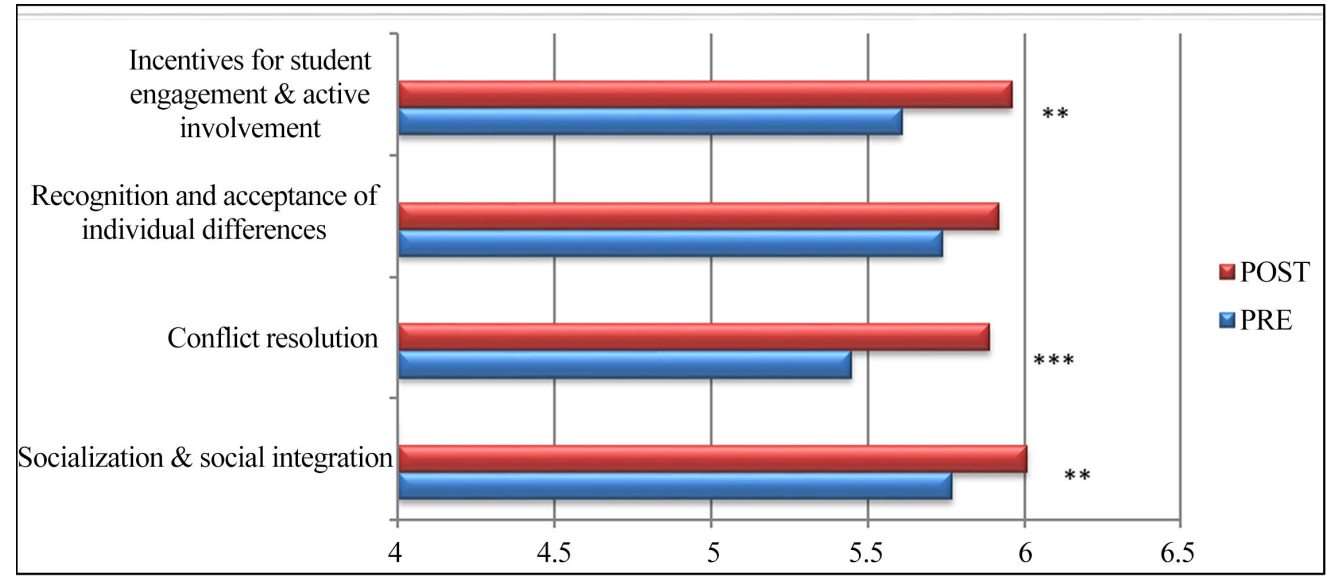

Figure 10. Means $(M)$, Standard Deviations $(S D)$ and Differences ( $F$-values) among pre-measure and post-measure regarding the Contribution of the Education for Entrepreneurship and Ethics. ${ }^{\star} p<.05$, ${ }^{* *} p<.01,{ }^{* * *} p<.001$. 
and social integration $\left.\left(F=5.994, p<.05, \eta_{p}^{2}=.020\right), 2\right)$ students' ability to resolve conflicts $\left(F=10.786, p<.001, \eta_{p}^{2}=.036\right)$, and 3$)$ the incentives for students' engagement and active involvement $\left(F=8.570, p<.01, \eta_{p}^{2}=.029\right)$.

\section{Discussion-Conclusions-Recommendations}

Based on the students' responses, the results showed statistical significant differences among pre- and post-measure regarding their views on entrepreneurial education, skills and the Education for Entrepreneurship and Ethics. In general, in the post-measure, the students revealed higher mean values, compared to the pre-test values.

More specifically, in the post-measure, which is after the training course, compared to the pre-measure, before the training course, the students when asked for the meaning of Entrepreneurial Education showed higher mean values in the object construction for charity or other purpose and the sale of students' constructions for various activities (e.g., seminars, excursions etc.). This means that they expanded their view on entrepreneurial education, which refers not only to the creation of a virtual enterprise, assuming roles in school activities (e.g. theatre, robotics), the formation of the school space (e.g. cleaning, painting) and the creation and publication of school newspaper, but also to object construction and sale. Many programs and courses, especially those that apply creative techniques, have led to enhanced entrepreneurial knowledge giving students a clearer view on what entrepreneurship is and what an entrepreneur does (European Commission, 2015).

Moreover, in the post-measure the students showed higher mean values, compared to the measure before the training course, in all the entrepreneurial skills, i.e. problem solving and responsible decision making, critical \& creative thinking, innovation, communication and interaction, risk-taking. Fiet (2014) also found that entrepreneurial education is positively related to students' entrepreneurial attitudes and skills. Johannisson (2010) and Amabile \& Kramer (2011) perceive entrepreneurial education as a means to achieve more interest, joy, engagement and creativity among students. According to Jones \& Iredale (2010), people need entrepreneurial skills and abilities to thrive in an ever-changing world.

In addition, in the post measure, compared to the pre-measure, all students from the three countries showed higher mean values in the following responses which refer to the entrepreneurship and ethics concepts: values, justice, cooperation and freedom of opinion and expression. Blenker, Korsgaard, Neergaard, \& Thrane (2011) propose a model which supports that entrepreneurial education can lead to many kinds of value and to a mindset that can be applied to all walks of life.

Finally, in the post-measure, compared to the pre-measure, students also showed higher mean values regarding the benefits of the Education for Entrepreneurship and Ethics, indicating that they believe that education for entrepreneurship and ethics contributes in: 1) students' socialization and social integra- 
tion, 2) students' ability to resolve conflicts, and 3) providing motivation for students' engagement \& active involvement. Many researchers (Deuchar, 2007; Moberg, 2014; Surlemont, 2007) have also found that entrepreneurial activities have an effect on students' engagement and motivation in education.

Conclusively, in almost all responses in the measure after the training course the students showed higher mean values than before the training course, supporting the positive impact of the course. Moreover, it is of great importance to mention that the pilot course "ETHICSBOARD" affected not only students', but also teachers' knowledge and views on the educational methods and techniques that seem to cultivate students' entrepreneurial skills (Tsoli, Babalis, Giouli, \& Kaboli, n.d.). In general, the study not only showed the capacity of entrepreneurial education to trigger deep learning and instill engagement, involvement, motivation, justice, freedom of opinion expression and feelings of cooperation and interaction among students, but also evidenced effects on the meaning of entrepreneurial education, innovation and other entrepreneurial skills and the relation between entrepreneurship and ethics.

Of course, several limitations of the study were identified. Firstly, due to the small size of the sample we did not compare the results based on students' nationality and age. Moreover, the academic standard of the sample was not considered in this study. In addition, the researchers constructed a self-assessment questionnaire, that can be subjective because students may not be sincere and may even over-evaluate their own performance. Finally, the implementation of a joint program and the distribution of the same questionnaire to students in three different countries could face obstacles related to the cultural particularities and special educational policies applied by each country.

Some recommendations deriving from this study are:

1) For policy:

- All countries should design and implement policies and programs to promote entrepreneurship.

- Policy makers should support efforts to increase entrepreneurial education and develop a unified model from primary, through secondary and further to higher education.

- Entrepreneurial education should be included in teacher initial and continuing training.

- Schools and universities should formalize entrepreneurship as an important part of the curriculum.

2) For practice and research:

- Teachers and researchers should share the lessons learned and best practices from such approaches/programs.

- There should be an increased awareness of entrepreneurial education as a pedagogical approach relevant to all students and on all levels of education.

- More studies examining the impact of entrepreneurial education programs should be designed and applied identifying also differences regarding age, gender, educational context, level, etc. 


\section{Acknowledgements}

The authors would like to thank the European Commission on the financial support of this project.

\section{Conflicts of Interest}

The authors declare no conflicts of interest regarding the publication of this paper.

\section{References}

Amabile, T., \& Kramer, S. (2011). The Progress Principle: Using Small Wins to Ignite Joy, Engagement, and Creativity at Work. Harvard Business Review Press.

Babalis, T., \& Tsoli, K. (2017). Classroom Life: Shaping the Learning Environment, Classroom Management Strategies and Teaching Techniques. Nova Publishers.

Blenker, P., Korsgaard, S., Neergaard, H., \& Thrane, C. (2011). The Questions We Care About: Paradigms and Progression in Entrepreneurship Education. Industry and Higher Education, 25, 417-427. https://doi.org/10.5367/ihe.2011.0065

Danish Foundation for Entrepreneurship (2014). Impact of Entrepreneurship Education in Denmark - 2014. Danish Foundation for Entrepreneurship. https://www.ffe-ye.dk

Deuchar, R. (2007). Citizenship, Enterprise and Learning: Harmonising Competing Educational Agendas. Trentham Books.

Erkkilä, K. (2000). Entrepreneurial Education: Mapping the Debates in the United States, the United Kingdom and Finland. Taylor \& Francis.

European Commission (2006). Key Competences for Lifelong Learning. European Commission. https://eur-lex.europa.eu/legal-content/EN/TXT/?uri=LEGISSUM:c11090

European Commission (2008). Final Report of the Expert Group Entrepreneurship in Higher Education, Especially within Non-Business Studies. European Commission.

European Commission (2013). Entrepreneurship 2020 Action Plan: Reigniting the Entrepreneurial Spirit in Europe, Communication from the Commission to the European Parliament, the Council, the European Economic and Social Committee and the Committee of the Regions. European Commission.

European Commission (2015). Entrepreneurship Education: A Road to Success. A Compilation of Evidence on the Impact of Entrepreneurship Education Strategies and Measures. Publications Office of the European Union.

European Commission/EACEA/Eurydice (2016). Entrepreneurship Education at School in Europe. Eurydice Report. Luxembourg: Publications Office of the European Union

Farrell, L. (2018). The Entrepreneurial Attitude: Lessons from Junior Achievement's 100 Years of Developing Young Entrepreneurs. McGraw-Hill.

Fiet, J.O. (2014). The Relationship between Entrepreneurship Education and Entrepreneurial Intentions: A Meta-Analytic Review. Entrepreneurship Theory \& Practice, 38, 217-254. https://doi.org/10.1111/etap.12095

Gibb, A. (2005). The Future of Entrepreneurship Education-Determining the Basis for Coherent Policy and Practice? In P. Kyro, \& C. Carrier (Eds.), The Dynamics of Learning Entrepreneurship in a Cross-Cultural University Context (pp. 44-67). University of Tampere, Research Centre for Vocational and Professional Education.

Global Entrepreneurship Monitor (GEM) (2020). Informe GEM España 2019-2020. Editorial de la Universidad de Cantabria. 
Johannisson, B. (2010). The Agony of the Swedish School When Confronted by Entrepreneurship. In K. Skogen, \& J. Sjovoll (Eds.), Creativity and Innovation. Preconditions for Entrepreneurial Education (pp. 91-121). Tapir Academic Press.

Jones, B., \& Iredale, N. (2010). Enterprise Education as Pedagogy. Education and Training, 52, 7-18. https://doi.org/10.1108/00400911011017654

Katz, J. A. (2003). The Chronology and Intellectual Trajectory of American Entrepreneurship Education 1876-1999. Journal of Business Venturing, 18, 283-300. https://doi.org/10.1016/S0883-9026(02)00098-8

Kohlberg, L. (1984). The Psychology of Moral Development. Harper and Row.

Lackéus, M. (2014). An Emotion-Based Approach to Assessing Entrepreneurial Education. International Journal of Management Education, 12, 374-396. https://doi.org/10.1016/j.ijme.2014.06.005

Lackéus, M. (2015). Entrepreneurship in Education. What, Why, When, How. Entrepreneurship360, Background Paper, European Commission: OECD.

Lickona, T. (1991). An Integrated Approach to Character Development in the Elementary School Classroom. In J. Benninga (Ed.), Moral, Character, and Civic Education (pp. 67-83). Teachers College Press.

Moberg, K. (2014). Two Approaches to Entrepreneurship Education: The Different Effects of Education for and Through Entrepreneurship at the Lower Secondary Level. The International Journal of Management Education, 12, 512-528. https://doi.org/10.1016/j.ijme.2014.05.002

Surlemont, B. (2007). Promoting Enterprising: A Strategic Move to Get Schools' Cooperation in the Promotion of Entrepreneurship. In A. Fayolle (Ed.), Handbook of Research in Entrepreneurship Education: Contextual Perspectives (Vol. 2, Chapter 16). Edward Elgar.

Tabachnick, B. G., \& Fidell, L. S. (2006) Using Multivariate Statistics (5th ed.). Allyn and Bacon.

Tsoli, K., \& Babalis, T. (2021). A Comparative Study on Teachers' Views on Entrepreneurial Education. In L. Gómez Chova, A. López Martínez, \& I. Candel Torres (Eds.), INTED2021 Proceedings 15th International Technology, Education and Development Conference (pp. 7598-7605). IATED Academy. https://doi.org/10.21125/inted.2021.1530

Tsoli, K., Babalis, T., Giouli, E., \& Kaboli, G. (n.d.). Developing Entrepreneurial Skills in Primary and Secondary School Students in Europe: The Views and Role of Teachers. In V. Papavassiliou, G. Xanthakou, N. Andreadakis, E. Nikolaou, \& M. Kaila (Eds.), Biodiversity, Social and Cultural Diversity. Diadrassi.

Volkmann, C., Wilson, K. E., Mariotti, S., Rapuzzi, D., Vyakarnam, S., \& Sepulveda, A. (2009). Educating the Next Wave of Entrepreneurs. Unlocking Entrepreneurial Capabilities to Meet the Global Challenges of the 21st Century. Report on Entrepreneurship Education, World Economic Forum.

Weinstein, B. (2009). Is It Still Cheating, If I Don't Get Caught? Flashpoint. 